\title{
Poetry Teaching and Multimodality: Theory into Practice
}

\author{
Daniel Xerri \\ Department of English, Junior College, University of Malta, Msida, Malta \\ Email: daniel.xerri@um.edu.mt \\ Received May $31^{\text {st }}, 2012$; revised June $30^{\text {th }}, 2012$; accepted July $11^{\text {th }}, 2012$
}

\begin{abstract}
This article discusses the theoretical concepts underpinning a multimodal approach to poetry teaching and considers a number of ways in which this can be adopted in practice. It discusses what is entailed by the concept of multimodality and examines the claims made about the benefits of employing a multimodal approach. It reviews the literature on multimodality and examines how teachers may blend a variety of techniques and resources in order not just to engage their students with poetry but also to activate language learning. In particular, this article examines how by tapping students' visual and digital literacy skills they are enabled to create video poems, podcasts, hypertexts and Wikis, all of which represent new ways of using language and experiencing poetry. Through constant reference to the research carried out so far, this article seeks to show how by means of a multimodal approach poetry can act as a springboard for the development of students' language proficiency and creative engagement.
\end{abstract}

Keywords: Poetry; Multimodality; Student Engagement; Digital Technology

\section{Introduction}

In recent years one of the most influential approaches to the teaching and learning of poetry is that emphasising multimodality, which is increasingly renowned as an effective way of enhancing students' engagement. This is probably due to the idea that "contemporary culture is marked by an intense pluralism and heterogeneity" and hence poetry can no longer be simply "evaluate[d] ... in terms of its formal devices" but "an interdisciplinary outlook" is required (Gilbert, 2006: pp. 1-2). This article examines the theoretical foundations of a multimodal approach to poetry teaching and evaluates different ways in which theory can be translated into practical applications. It is because of the potential of digital tools as a means of engaging students as well as an awareness of the possibility that in some educational contexts students might not be availing themselves fully of such potential, that ample room is given to a discussion of the use of multimedia and hypermedia in the classroom. Ultimately, the chief interest of this article is to show that by means of a multimodal approach teachers can enable students to enter a poem, play with the English language and transform poetry into a performance.

\section{Multimodality}

Multimodality is defined as "the use of several semiotic modes in the design of a semiotic product or event, together with the particular way in which these modes are combined" (Kress \& Van Leeuwen, 2001: p. 20). For Dressman (2010) it is "the crafted integration of two or more ways, or modes, of communication, so that their combined meaning as a whole is greater than either mode separately or their simple combination" (p. 71). This usually, but not exclusively, involves the use of digital technology and it is this particular aspect of multimodality that I consider to be of pressing concern for the purposes of this article.

Given the different and evolving ways of communication that contemporary students can utilise to communicate meaning and understand the world, a multimodal approach is necessary. According to the New London Group (1996) "One of the key ideas informing the notion of multiliteracies is the increasing complexity and inter-relationship of different modes of meaning” (p. 78). What relates different design elements (i.e. linguistic, visual, audio, gestural and spatial) to each other are "the Multimodal patterns of meaning"(New London Group, 1996: p. $65)$. Given that "all meaning-making is multimodal" the latter is considered to be "the most significant, as it relates all the other modes in quite remarkably dynamic relationships" (New London Group, 1996: pp. 80-81). The "transformation" of texts that is allowed by digital technology means that "as a way of reflecting on text, exploring and experimenting with it in a new medium can offer insights into and shifts of meaning that can well be characterized as refraction" (Tweddle et al., 1997: p. 54). Unsworth (2001) refers to "technoliteracies" and in his opinion these will not supplant traditional literacies but complement them, especially since "hard-copy forms of 'linear' texts will continue to co-exist with electronic hypertext for some time" (p. 281). Hence "the work of the English teacher clearly involves developing students" use of multiliteracies in the composition and comprehension of texts in computer based and "conventional formats" as well as "developing students" meta-semiotic understanding and the associated meta-language' (Unsworth, 2001: p. 282).

A multimodal approach presents students with different potentials for engagement with a text: the point of entry, the possible paths through a text and the potentials for re-making it. In multimodal texts, each mode offers a different way into representation and focuses on different aspects of meaning (Jewitt, 2005: p. 7).

In Alvermann's (2009) opinion "reaching and teaching adolescents in currently changing times will require a healthy respect for their past, present, and future literacies" (p. 105). This issue is particularly significant given the fact that most con- 
temporary English syllabi might not yet make any reference to multimodal texts or to any conjunctive literacies.

\section{Digital Technology in the Classroom}

Tweddle et al. (1997) emphasise the fact that "the changes enabled and driven by technology have become so far-reaching that for English teachers to ignore them would prove ultimately irresponsible" (p. 6). In Malta, for example, the process of training teachers to teach by means of ICT has been going on since 1998 and the government admits to investing heavily in ICT training for teachers (Galea, 2001; Zammit, 2004; Ministry for Infrastructure, Transport and Communications, n.d.). However, Zammit and Mifsud (2003) report that computer assisted learning influences teaching least as a pedagogical approach in the foreign language classroom in Malta (p. 145). Despite its ever growing accessibility, Unsworth et al. (2005) generalize by saying that "the majority of teachers... are in need of guidance" (p. 1) when it comes to using ICT in an effective manner in the classroom. This is something that a number of sources also call for (NATE, 2007; Azzopardi, 2008; Ćukušić et al., 2008; Granić et al., 2009). For example, the Institute for Learning (2010) notes that "the evidence collected from learners suggested that only a very few teachers are using technology in the most effective way" (p. 11) while an EU research report states that "personal and pedagogic digital competence need to become a priority in both ITT and CPD, because lack of ICT skills and understanding of its benefits is a major obstacle for many teachers" (Cachia et al., 2010, p. 47).

Unsworth et al. (2005) believe that "the use of computers in English teaching can enhance and extend the engagement of computer-age children with the enchantment of the possible worlds of literary narratives" (p. 1), what Burn and Durran (2007) call "pleasure and critical engagement" (p. 12). McVerry (2007) believes that 'In order to construct knowledge in today's world students must be fluent with multimodal text' ( $p$. 51) while Bennett et al. (2008) postulate that "Education may be under challenge to change" (p. 783) in order to meet the needs of digital natives. Hughes (2009) maintains that "Ignoring this phenomenon in our classrooms would be a mistake. If we do so, we run the risk of losing touch and school may become boring and irrelevant for students as a result" (p. 18). That is why "A common justification for using digital technology in the classroom is its potential for interactivity" (Hughes, 2009: p. 185), which thus makes it highly relevant to this article's concern with poetry pedagogy. In Miller's (2010) opinion this entails revaluating teacher education: "Preparing teachers for the 21 st-century digital world... requires teacher educators to take up the pressing issue of effective pedagogical frameworks for multimodal composing", with the ultimate aim being 'to engage millennial students in school' (p. 198). This is confirmed by Cachia et al. (2010) who indicate that "Teachers... should receive more support in integrating technology into their teaching" so that "students can express their creativity and innovation with technologies" (p. 47).

\section{No Panacea}

Despite all its apparent benefits, the multimodal approach must not be deemed to be some kind of magical remedy. Systematic reviews conducted by the English Review Group within the EPPI-Centre sought to ascertain whether the supposed benefits of ICT on literacy learning could be verified by the literature and thus whether policy-makers' investment in ICT is warranted. They found that even though most studies assume that networked ICT has a positive impact on students' literacy, ICT needs to be considered one of many tools that can improve and support literacy learning (Andrews et al., 2002). In fact, another review and meta-analysis of the effectiveness of ICT on literacy found that most small-scale studies yielded minimal evidence of benefit (Torgerson \& Zhu, 2003). This indicates the need to avoid reaching conclusions based on little scientific proof. For example, a Maltese study on ICT as a literacy aid for students reports that teachers and parents are under the impression that digital technology has a positive impact on children's literacy, however, this study merely describes perceptions and does not present any evidence to corroborate such perceptions (Azzopardi, 2008).

After reviewing studies focusing on the impact of ICT on literature-related literacies, the English Review Group found that teachers mediate impact and hence they can be considered to be more significant than technology (Locke \& Andrews, 2004). Moreover, despite a number of reported benefits, such as an improvement in writing skills, increased collaboration, lesson enjoyment and motivation, the English Review Group could not identify clear and definite evidence of the impact of ICT on the literacy of students for whom English is a second or additional language (Low \& Beverton, 2004). Another review investigating the impact of ICT on students' moving image literacy in English found that to some extent the use of moving image media can lead to improved literacy and an increase in motivation (Burn \& Leach, 2004). Andrews (2004) sums up the findings of the English Review Group by saying that "Teachers should be aware that there is no evidence that non-ICT methods of instruction and non-ICT resources are inferior to the use of ICT to promote literacy learning" (p. 210). However, he does concede that "ICT can help create more motivated ESL/EAL learners" (Andrews, 2004: p. 210). Hence what this seems to suggest is that despite the supposed benefits of ICT, it must not be deemed a panacea for all literacy and student engagement problems.

In fact, while underscoring the need for teachers to incorporate digital technology in their English lessons, a National Association for the Teaching of English (NATE, 2007) position paper calls for a "truly broad and balanced curriculum" and thus "celebrate[s] all that writing in its many forms has to offer" and "espouse[s] the value of just learning to read, of enjoying reading for the sake of our imaginations and creativity and what this offers to our ability to create, generate and communicate ideas" (p. 5). Such prudence is also characteristic of a NATE (2009) entitlement document, in which it is stated that ICT "has unique potential to extend and enhance students" learning in English. Used appropriately and imaginatively, "it provides possibilities, insights and efficiencies that are difficult to achieve in other ways' (p. 1). Such a balanced outlook is what informs this article's inquiry into the role that multimodality plays in the teaching of poetry.

\section{Multimodal Teaching and Learning}

The notion of multimodality redefines pedagogy because learning itself is reconceptualised, partly because of the impact of new technologies. For example, Kress (2003) argues that "the increasingly and insistently more multimodal forms of 
contemporary texts make it essential to rethink our notions of what reading is" (p. 141). This is partly because "the demands on readers, and the demands of reading, will if anything be greater, and they will certainly be different" (Kress, 2003: p. 167). In the USA the National Council of Teachers of English (NCTE) indicates that the definition of literacy for 21 st century classrooms goes beyond the traditional ability to read and write print texts but also incorporates the sense of reading and writing multimodal texts (NCTE, 2005, 2008).

McBride (2004) feels that those who teach the humanities need to "reconceptualise the intersections between the humanities classroom and visual rhetoric" (p. xix). This is important because just like language and literature, "film is a signifying practice through which students make meaning"; its use in the classroom leads to "active and engaged viewers who must participate in the viewing experience in order to create meaning" (McBride, 2004, p. xiii). According to Jewitt (2005) "The multimodal character of new technologies requires a re-thinking of learning as a linguistic accomplishment" (p. 8). In her opinion "The almost habitual conjunction of 'language', speech and writing, with learning is... especially paradoxical in relation to technology-mediated learning" given that speech and writing are "a small part of a multimodal ensemble" (Jewitt, 2005: p. 2). For Kress et al. (2005) "A multimodal approach is one where attention is given to all the culturally shaped resources that are available" (p. 2). They consider it "essential" due to "the ways in which it creates new kinds of identity for students and teachers" (Kress et al., 2005: p. 14). It may actually lead to a reevaluation of the teacher/learner hierarchy: "changing learners in changing times may eventually alter how we, as teachers and teacher educators, view the expert/novice relationship" (Alvermann, 2009: p. 102). This is particularly significant when one takes into consideration the traditional role of poetry teachers as gatekeepers to a poem's meaning.

The adoption of a multimodal approach has implications for the teaching and learning of writing in particular. Kress (2010) claims that "Writing, previously the canonical text par excellence, is giving way to image" (p. 133). Genres have become "fluid and insecure; representation, understood now as multimodal, is no longer dependably canonical. There is choice. What genre to use; how to reshape it; what modes to use for what purpose and for which audience" (Kress, 2010: p. 132). Archer (2010) feels that "understanding how language and images interact to create meaning is crucial for reconceptualising writing pedagogy from a multimodal perspective" (p. 209). In her opinion "We need to redefine writing pedagogy through the development of metalanguages that will facilitate awareness and analysis of multimodal textual construction" (Archer, 2010, p. 212). Edwards-Groves (2010) argues that the act of reconceptualising "writing and text construction as the multimodal writing process... balances the more dominant written-linguistic modes of text construction... with dynamic elements of design" (p. 63). She urges teachers to "step slowly with their students in learning to write multimodally and adjust pedagogical practices" (Edwards-Groves, 2010: p. 63). This is especially pertinent to educational contexts in which an inordinate amount of emphasis is placed on traditional writing practices.

\section{A Multimodal Approach to Poetry Teaching}

A multimodal poetry teaching methodology is seen as having the potential to be effective in boosting students' engagement.
Dymoke and Hughes (2009) are convinced of "the powerful, dynamic and multimodal nature of poetry which is... a key justification for its inclusion in a 21 st-century curriculum" (p. 93). They remind us of the fact that the word text originates from the Latin verb texere, meaning to weave, and highlight the example of "a digital space" within which "a multimodal text can be woven by many makers who are also users/readers of that text" (Dymoke \& Hughes, 2009: p. 93). Hughes (2009) thinks that "we have suppressed poetry's multimodal nature too long within the confines of the print text... Students are immersed daily in new media, the cultural tools of their time, and we must redefine our literacy practices in order to stay relevant" (p. 230). According to Blake (2009) a multimodal approach helps teachers to "develop an engaged enjoyment and appreciation of poetry" as well as "creative and critical thinking” (p. 28) during their lessons. Dymoke (2009) argues that "poetry is a playful, multimodal medium rather than one destined to be stranded for ever on the printed page" and she urges teachers to do their utmost to keep it so:

If you leave poetry on the page in your classroom you will be in danger of sounding its death knell: it is an organic, enriching communication tool, which taps into all our senses and is constantly renewing and reinventing itself to afford us new ways to express ourselves... If poetry is to flourish in any future English curriculum and in your classroom and if you are to flourish as a creative poetry teacher, then you should embrace the multimodal experiences poetry can offer (pp. 80-81).

Snapper (2009) agrees with this and claims that "Teachers also know that poetry can be "brought to life" for students by translating it from the printed page to other media" (p. 2). The benefits of this seem to be clearly evident in the classroom as attested by an Ofsted (2009) report that describes how amongst a number of lessons deemed "fun" by students, one particular poetry lesson was observed to make use of "a range of media to stimulate imagination" (p. 12). This approach was "particularly suited to a class where English was not most students' first language" (Ofsted, 2009, p. 12), a characteristic of most contemporary international English learning contexts.

\section{Blending Visual and Print Media}

The blending of visual and print media is perhaps the most popular form of multimodality. Albers (2006) describes a multimodal approach to teaching poetry in which "the visual mode may support students' initial learning of concepts and approaches to analysis, followed then by the written mode, or the poem" (p. 87). In McVerry's (2007) opinion "The nature of poetry as a genre, with its reliance on imagery offers a wonderful opportunity to develop awareness in students about the role of multimedia in meaning making" (p. 53).

The visual is given a lot of importance by the literature on pedagogy and some consider it to be the key to student engagement (Kress, 2003). For example, in my experience video poems do make a difference to student engagement; the opportunities they afford for discussion, critical thinking and collaboration mean that students are not only honing their linguistic skills but a host of other literacies as well. This seems to tally with research conducted in the USA and in the UK with ESL students, which identified a number of benefits to the act of using video poems in the classroom. These benefits are not 
solely of a linguistic nature even though video poems can provide students with a means of developing their language proficiency and making them more active readers.

Miller (2007) affirms that as soon as digital video composing is practised in the classroom "what can happen is startling: merging curriculum with student lifeworlds, democratizing media production, repositioning students as competent, bridging from multimodal to academic and critical literacies" (p. 79). She reports that the results of one particular digital video project show how students developed into "more active readers and composers as they pursued their own understandings through digital video composing. In orchestrating the visual, music, and narrative for a poetry video...the teachers and their students performed their knowing; it was dynamic, evolving, and constructed" (Miller, 2007: p. 71). Comparably, McVee et al. (2008) describe how:

As students began to think about how a poem could be represented visually, aurally, or through on-screen movement, they focused on how to communicate the meanings that they wanted others to experience. This moved them away from fears that they would not produce a "correct" interpretation. Instead, they were intent on exploring various modalities to communicate meanings they were discovering (p. 132).

The above is in concordance with the idea that "A poem accompanied by visual images can be seen as a new text, a different way of performing the poem" (Hughes, 2009: p. 204). Moreover, visual poetry is considered an effective means of encouraging students to enjoy the reading and discussion of poetry (Templer, 2009).

The NATE (2008) project report entitled "Making hard topics in English easier with ICT" contains a number of case studies that specifically deal with the teaching of poetry in a multimodal manner, especially through the incorporation of visual technology. For example, Mortlock (2008) discovered that lowachieving students' "motivation, self-esteem and understanding of the poetry was improved by their use of Movie Maker to create short videos about poems they were studying" (p. 33). Similarly, Charles (2008), using Movie Maker with students whose first language was not English, realized that "his students gave much more spontaneous responses than in the normal classroom situation and gained confidence in expressing their own opinions" (p. 39). These students not only "used the poetry to expand and explore their own views of the world' but their "use and knowledge of the English language increased" (Charles, 2008: p. 41). Moreover, "poetry in the curriculum could be explored in an engaging and entertaining manner" (Charles, 2008: p. 41). Tippings (2008) "had previously found that students in her school, particularly the boys, were resistant to poetry", however, the act of presenting poetry in a visual manner through the use of ICT "resulted in increased engagement and sustained interest through a series of lessons" (p. 45).

\section{Reviving the Aural Tradition}

Audio recordings of poetry have of course long existed and thus there is nothing really new about poets recording their poems. However, the Internet has allowed teachers and students to gain access to a huge amount of poetry recordings and to use them during their English lessons. Both poetryarchive.org and poets.org are highly popular collections of such recordings and they have the added advantage of offering teachers a wealth of teaching ideas. Talking about how teachers may adopt a multimodal approach to the teaching of poetry by using the resources of the Poetry Archive, Blake (2008) says that:

The recordings of poets reading their own work make poetry a more magical and swirling matter of expression and interpretation, something linked to real people and their individual voices and not the nigh-on-impossible Enigma code-breaking activity that it often seems to get represented as in the daily workings of School English (p. 28).

Sprackland (2008) agrees with this and claims that by listening to a poet reciting a poem, students are provided with "a powerful source of insight, understanding and enjoyment” (p. 30).

Even though audio recordings of poetry have long been in existence, some teachers have taken this a step further and are asking students to produce their own recordings by means of digital technology, which helps make the whole process more powerful and accessible. Digital technology makes it easier for students not only to record their own poems or thoughts about poetry but also to publish these online in the form of podcasts, thus motivating students by providing them with a real audience. The poetryfoundation.org serves as a good model of how to go about it while there exist a variety of websites that allow students to create podcasts and publish them online and thus reach a wider audience.

Research seems to suggest that students not only develop a strong engagement with poetry by means of podcasts but they also enhance a variety of language skills, especially speaking and listening. Murphy (2008), for example, encouraged her students to analyse the language of poetry by collaboratively producing podcasts and found that they "developed speaking and listening skills, learnt new ICT skills, really engaged with the poems they were studying - and perhaps most importantly seemed to be having fun" (p. 107). In a similar fashion McMillan used podcasting to improve students' close analysis of the language in poetry and "results appear to show pupils talking engagingly, enjoyably and knowledgeably about poetry-often with [an] increased awareness of language" (p. 113). One of the reasons for this is that "students regard speaking for a real audience as motivating" (McMillan, 2008: p. 117). The Internet is partly what provides students with such an audience and it forms an integral part of a teacher's multimodal approach because it "is making it possible to revive the aural tradition and restore to us the imaginative joys of listening. Real, concentrated listening is a creative as well as an interpretive experience" (Sprackland, 2009: p. 22).

\section{Hypertexts}

The creation of hypertexts is another means of using a multimodal approach to poetry teaching. A hypertext is, simply put, a text that is linked to other texts by means of hyperlinks. It allows students to create dynamic texts that in a way cease being linear. When a traditional print poem is transformed into a hypertext or when students write a hypertext poem the latter is opened up by means of a number of hyperlinks that illustrate how the students have interpreted the imagery and diction in the poem while engaging in textual and linguistic experimentation. Thus the resulting poem does not have a definite sense of direction. It can be read in a variety of ways and readers can choose where they want to go. According to recent research this ele- 
ment of reader empowerment is the main value of hypertext poems.

A hypertext not only allows students to read poetry in a dynamic and non-linear manner but it also allows them to be creative and engaged writers of poetry (Kendall, 1998). Hughes (2009) explains that:

With the use of hypertext, new possibilities exist that allow students more power over their own texts and those of others. They can explore and create their own texts in multi-sequential ways... The hyperlinks also encourage readers to shape their involvement with the poem, to decide what to read and how to read it (p. 188).

However, even though a medium like hypertext has "a significant impact on teaching literature" it does not "relieve us of the duties of teaching reading, writing, and critical thinking" (Browner et al., 2000: p. 130).

\section{Wikis}

Wikis, a series of web pages that can be edited through a browser, are a great way of encouraging students to collaborate in writing and editing poetry. There exists a number of very popular poetry Wikis that are specifically aimed at ESL students and some of them are characterised by the fact that they devote a substantial amount of room to what students can gain in linguistic terms from the reading of poetry. It is relatively easy for a teacher to set up a poetry Wiki and by reserving a section of the Wiki to language games students can be encouraged to develop an increased awareness of language while reading, writing and discussing poetry.

Studies show that Wikis not only help students to bolster their language skills but they also make teachers more confident writers. Dymoke and Hughes (2009) emphasise the idea that by using a digital tool like a Wiki, teachers not only "gain confidence in their ability to write poetry and to reflect on themselves as writers" but can also learn to "exploit the multimodal affordances of the Wiki for composing and teaching poetry more fully" (pp. 101-102). Richardson (2008) found that using a Wiki for poetry teaching purposes facilitated "conversations about poetry" between different groups and "gave all students, no matter what ability, a voice and enabled them to ask questions themselves and interrogate texts naturally" (p. 65).

\section{Other Forms of Multimodality}

Besides the different digital media discussed above, teachers can also emphasise poetry's multimodal nature by means of activities like poetry slams, during which students compete at performing published or original poetry and which are sometimes modelled on popular TV talent shows (The Guardian, 2009). These "help young people to gain confidence through a dynamic engagement with the written and spoken word" (Dymoke, 2009: p. 81). By being "both inclusive and challenging' such activities allow students "to gain a much greater understanding and appreciation of how language and structure create effects and convey meanings" (Dymoke, 2009: p. 82).

\section{Conclusion}

The focus of this article has mostly extended to the use of digital media because this particular aspect of multimodality is a key priority for all those teachers hoping to engage digital natives with the reading of poetry. As Hughes (2009) points out "Immersing students in a digital environment that serves as a model for their own digital performances views performance as a purposeful and creative process interwoven with other literacy events" (p. 228). Multimodality allows teachers to harness poetry's communicative potential, however, despite all the advantages of a multimodal approach, teachers are still the most significant factor when it comes to inspiring students' reading habits. Digital technology has the potential of making the learning experience a more engaging one and of lifting a poem off the printed page but it is certainly not the panacea for all the challenges that teachers face when attempting to engage students with poetry.

\section{REFERENCES}

Albers, P. (2006). Imagining the possibilities in multimodal curriculum design. English Education, 38, 75-101.

Alvermann, D. E. (2009). Reaching/teaching adolescents: Literacies with a history. In J. V. Hoffman, \& Y. M. Goodman (Eds.), Changing literacies for changing times: An historical perspective on the future of reading research, public policy, and classroom practices (pp. 98-107). New York: Routledge.

Andrews, R. (2004). Conclusion. In R. Andrews (Ed.), The impact of ICT on literacy education (pp. 202-214). London: Routledge Falmer.

Andrews, R., Burn, A., Leach, J., Locke, T., Low, G., \& Torgerson, C. (2002). A systematic review of the impact of networked ICT on 5 - 16 year olds' literacy in English. London: EPPI-Centre, Social Science Research Unit, Institute of Education, University of London.

Archer, A. (2010). Multimodal texts in Higher Education and the implications for writing pedagogy. English in Education, 44, 201-213. doi:10.1111/j.1754-8845.2010.01073.x

Azzopardi, M. (2008). Perceptions about the use of computers as literacy aids for young learners. B.Ed. Dissertation, Malta: University of Malta.

Bennett, S., Matton, K., \& Kervin, L. (2008). The "digital natives" debate: A critical review of the evidence. British Journal of Educational Technology, 39, 775-786. doi:10.1111/j.1467-8535.2007.00793.x

Blake, J. (2008). The magpie teacher on poetry and storytelling. NATE Classroom, 4, 27-29.

Blake, J. (2009). Using the Poetry Archive in the English classroom. English Drama Media, 13, 24-28.

Browner, S., Pulsford, S., \& Sears, R. (2000). Literature and the Internet. New York: Garland Publishing.

Burn, A., \& Durran, J. (2007). Media literacy in schools: Practice, production and progression. London: Paul Chapman Publishing.

Burn, A., \& Leach, J. (2004). A systematic review of the impact of ICT on the learning of literacies associated with moving image texts in English, 5-16. London: EPPI-Centre, Social Science Research Unit, Institute of Education, University of London.

Cachia, R., Ferrari, A., Ala-Mutka, K., \& Punie, Y. (2010). Creative learning and innovative teaching: Final report on the study on creativity and innovation in education in the EU member states. Luxembourg: European Union.

Charles, T. (2008). Poetry for SEN and EAL students. In Making hard topics in English easier with ICT (pp. 39-44). Sheffield: NATE. URL (last checked 27 March 2012).

http://www.nate.org.uk/cmsfiles/ict/h2t/NATE_Hard_to_Teach_Case Studies.pdf

Ćukušić, M., Granić, A., Mifsud, C., \& Zammit, M. (2008). A best practice approach to the enhancement of the learning experience. In D. Remenyi (Ed.), The proceedings of the $7^{\text {th }}$ European conference on e-learning (Vol. 1, pp. 253-263). Reading: Academic Publishing.

Dressman, M. (2010). Let's poem: The essential guide to teaching poetry in a high-stakes, multimodal world. New York: Teachers College Press.

Dymoke, S. (2009). Teaching English texts 11-18. London: Continuum. 
Dymoke, S., \& Hughes, J. (2009). Using a poetry Wiki: How can the medium support pre-service teachers of English in their professional learning about writing poetry and teaching poetry writing in a digital age? English Teaching: Practice and Critique, 8, 91-106.

Edwards-Groves, C. J. (2010). The multimodal writing process: Changing practices in contemporary classrooms. Language and Education, 25, 49-64. doi:10.1080/09500782.2010.523468

Galea, L. (2001). Creating new leaders for e-culture: Keynote address by the Maltese minister of education. Ministry of Education, Employment and the Family. URL (last checked 9 February 2012). http://www.education.gov.mt/ministry/doc/pdf/eCulture_Full.pdf

Gilbert, A. (2006). Another future: Poetry and art in a postmodern twilight. Middletown, CT: Wesleyan University Press.

Granić, A., Mifsud, C., \& Ćukušić, M. (2009). Design, implementation and validation of a Europe-wide pedagogical framework for e-Learning. Computers \& Education, 53, 1052-1081.

doi:10.1016/j.compedu.2009.05.018

Hughes, J. (2009). Poets, poetry and new media: Attending to the teaching and learning of poetry. Saarbrücken: VDM Verlag.

Jewitt, C. (2005). Technology, literacy and learning: A multimodal approach. London: Routledge.

Kress, G. (2003). Literacy in the new media age. London: Routledge. doi:10.4324/9780203164754

Kress, G. (2010). Multimodality: A social semiotic approach to contemporary communication. Abingdon: Routledge.

Kress, G., Jewitt, C., Bourne, J., Franks, A., Hardcastle, J., Jones, K., \& Reid, E. (2005). English in urban classrooms: A multimodal perspective on teaching and learning. Abingdon: RoutledgeFalmer.

Kress, G., \& Van Leeuwen, T. (2001). Multimodal discourse: The modes and media of contemporary communication. London: Arnold Publishers.

Locke, T., \& Andrews, R. (2004). A systematic review of the impact of ICT on literature-related literacies in English 5-16. London: EPPICentre, Social Science Research Unit, Institute of Education, University of London.

Low, G., \& Beverton, S. (2004). A systematic review of the impact of ICT on literacy learning in English of learners between 5 and 16, for whom English is a second or additional language. London: EPPICentre, Social Science Research Unit, Institute of Education, University of London.

McBride, K.D. (2004). Introduction. In K. D. McBride (Ed.), Visual media and the humanities: A pedagogy of representation (pp. xi-xix). Knoxville: University of Tennessee Press.

McMillan, C. (2008). Using podcasting to improve close analysis of language in poetry. In Making hard topics in English easier with ICT (pp. 113-130). Sheffield: NATE. URL (last checked 27 March 2012). http://www.nate.org.uk/cmsfiles/ict/h2t/NATE_Hard_to_Teach_Case Studies.pdf

McVee, M. B., Bailey, N. M., \& Shanahan, L. E. (2008). Using digital media to interpret poetry: Spiderman meets Walt Whitman. Research in the Teaching of English, 43, 112-143.

McVerry, J. G. (2007). Power of posting poetry: Teaching new literacies. Language Arts Journal of Michigan, 23, 51-56.

Miller, S. M. (2007). English teacher learning for new times: Digital video composing as multimodal literacy practice. English Education, 40, 61-83.

Miller, S. M. (2010). Reframing multimodal composing for student learning: Lessons on purpose from the Buffalo DV project. Contemporary Issues in Technology and Teacher Education, 10, 197-219.

Ministry for Infrastructure, Transport and Communications. (n.d.). The smart island: The national ICT strategy for Malta 2008-2010. URL (last checked 9 February 2012).

https://mitc.gov.mt/MediaCenter/PDFs/1_ICT\%20Strategy\%20200810.pdf

Mortlock, C. (2008). Engaging with poetry. In Making hard topics in English easier with ICT (pp. 33-38). Sheffield: NATE. URL (last checked 27 March 2012).

http://www.nate.org.uk/cmsfiles/ict/h2t/NATE_Hard_to_Teach_Case _Studies.pdf
Murphy, K. (2008). Analysing the language of poetry through podcasts. In Making hard topics in English easier with ICT (pp. 107-112). Sheffield: NATE. URL (last checked 27 March 2012).

http://www.nate.org.uk/cmsfiles/ict/h2t/NATE_Hard_to_Teach_Case Studies.pdf

National Association for the Teaching of English (2007). ICT in English: A NATE position paper. URL (last checked 8 February 2012). http://www.nate.org.uk/cmsfiles/ict/NATE_Position_Paper_on_ICT_ in_English.doc

National Association for the Teaching of English (2008). Making hard topics in English easier with ICT. Sheffield: NATE. URL (last checked 27 March 2012).

http://www.nate.org.uk/cmsfiles/ict/h2t/NATE_Hard_to_Teach_Case Studies.pdf

National Association for the Teaching of English (2009). Entitlement to ICT in secondary English. URL (last checked 10 February 2012). http://www.nate.org.uk/cmsfiles/ict/Seconday_English_entitlement_ document_2009.pdf

National Council of Teachers of English (2005). NCTE position statement: On multimodal literacies. URL (last checked 26 March 2012). http://www.ncte.org/positions/statements/multimodalliteracies

National Council of Teachers of English (2008). NCTE position statement: Definition of 21 st-century literacies. URL (last checked 26 March 2012). http://www.ncte.org/positions/statements/21stcentdefinition

New London Group (1996). A pedagogy of multiliteracies: Designing social futures. Harvard Educational Review, 66, 60-92.

Ofsted. (2009). English at the crossroads: An evaluation of English in primary and secondary schools, 2005/08. London: Ofsted.

Richardson, A. (2008). Building learning power with wikis. In Making hard topics in English easier with ICT (pp. 65-74). Sheffield: NATE. URL (last checked 27 March 2012).

http://www.nate.org.uk/cmsfiles/ict/h2t/NATE_Hard_to_Teach_Case Studies.pdf

Snapper, G. (2009). Editorial. English Drama Media, 13, 2-3.

Sprackland, J. (2008). The poetry archive. NATE Classroom, 4, 30.

Sprackland, J. (2009). The ear is the best reader. English Drama Media, 13, 21-23.

Templer, B. (2009). Poetry in motion: A multimodal teaching tool. Humanising Language Teaching, 11. URL (last checked 4 April 2012). http://www.hltmag.co.uk/oct09/sart06.htm

The Guardian (2009). Who's got the P factor? URL (last checked 21 March 2012).

http://www.guardian.co.uk/education/video/2009/jul/07/poetry-prima ry-schools

Tippings, L. (2008). Enlivening the study of poetry with Year 8. In Making hard topics in English easier with ICT (pp. 45-47). Sheffield: NATE. URL (last checked 27 March 2012).

http://www.nate.org.uk/cmsfiles/ict/h2t/NATE_Hard_to_Teach_Case Studies.pdf

Torgerson, C., \& Zhu, D. (2003). A systematic review and meta-analysis of the effectiveness of ICT on literacy learning in English, 5-16. London: EPPI-Centre, Social Science Research Unit, Institute of Education, University of London.

Tweddle, S., Adams, A., Clarke, S., Scrimshaw, P., \& Walton, S. (1997). English for tomorrow. Buckingham: Open University Press.

Unsworth, L. (2001). Teaching multiliteracies across the curriculum: Changing contexts of text and image in classroom practice. Buckingham: Open University Press.

Unsworth, L., Thomas, A., Simpson, A., \& Asha, J. (2005). Children's literature and computer based teaching. Maidenhead: Open University Press.

Zammit, L. (2004). ICT literacy and education in Malta. Department of Technology in Education. URL (last checked 11 February 2012). http://schoolnet.gov.mt/dtie/ICT\%20Literacy.doc

Zammit, M., \& Mifsud, C. (2003). Language learning and teaching in Malta. In D. Newby (Ed.), Mediating between theory and practice in the context of different learning cultures and languages (pp. 137148). Graz: Council of Europe. 